\title{
A SCRIBE OF ALL SIGNS OF WISDOM: REFLECTIONS ON GEORGE W.E. NICKELSBURG IN PERSPECTIVE
}

\author{
Matthias Henze \\ Rice University
}

The scholarly oeuvre of George W.E. Nickelsburg is shaped by a remarkable degree of consistency. His 1967 dissertation, Resurrection, Immortality, and Eternal Life in Intertestamental fudaism, subsequently published in 1972, marked the beginning of what would become a lifelong exploration of the literary and social diversity of Second Temple Judaism. ${ }^{1}$ Nickelsburg's interests, it is well known, lie primarily with the Old Testament apocrypha and pseudepigrapha, with sapiential and apocalyptic literature, and with the fragments from Qumran. The principal aim of his scholarship has always been to underscore the remarkable variety of early Judaism and to point to the significance that diversity has had for the emergence of Christianity. When in 1981 Nickelsburg published his Fewish Literature Between the Bible and the Mishnah, ${ }^{2}$ he helped the study of Second Temple Jewish literature become an academic field in its own right by giving it a richly informative and eminently reliable introduction. In a way the dissertation and the introduction also indicated the direction much of his subsequent scholarship would take, since his oeuvre has to a large degree been, and continues to be, a further systematic exploration of the texts and issues discussed already in these early works.

Now, over thirty years later, this consistent effort is bearing further fruit. With the publication of three major works during the last three years the tectonic plates are moving into position. In 2001 Nickelsburg published his formidable and already authoritative commentary on 1 Enoch, a text, which, as he explains in the preface

\footnotetext{
${ }^{1}$ Harvard Theological Studies 26. The dissertation was written under Krister Stendahl. 2 Fewish Literature Between the Bible and the Mishnah: A Historical and Literary Introduction (Philadelphia, 1981; paperback, 1987). The volumes were followed by his overviews, "Stories of Biblical and Early Post-Biblical Times," and "The Bible Rewritten and Expanded," both in M.E. Stone, ed., Fewish Writings of the Second Temple Period (Assen and Philadelphia, 1983), pp. 33-87, and 89-156, respectively.
} 
to the volume, has captured his imagination for three decades. ${ }^{3}$ Then, in 2003, two more books combining a total of over 1,000 pages followed. Though different in form, they are related in theme and purpose and are equally ambitious. In the first, Ancient Fudaism and Christian Origins, Nickelsburg offers a concise analysis of the theological contours of early Judaism. ${ }^{4} \mathrm{He}$ explains at the outset that since the 1950s "a revolution" in our understanding of ancient Judaism has been set in motion, triggered by the discovery of the Qumran scrolls, by refined methodologies borrowed from literary studies and the social sciences that make scholars more self-conscious about what it is they are doing, and by Christian reflections on the Holocaust, all of which led to the collapse of old Christian stereotypes of Judaism that previously had dominated scholarly perception. The book's five chapters follow traditional categories of the discipline: Scripture and Tradition; Torah and the Righteous Life; God's Activity in Behalf of Humanity; Agents of God's Activity; and Eschatology. Nickelsburg deliberately chose traditional categories in order to demonstrate how these need to be redefined in light of the recent changes in the field. Each chapter begins with a discussion of contemporary research on early Judaism, and then moves on to lay out the implications these new insights have for our understanding of Christian origins. In the end Nickelsburg seeks to provoke - above all his New Testament colleagues, it would appear - by arguing that the central corollary of the emerging new picture of Judaism is the need to reassess our theories about the emergence of Christianity. The need to redefine

31 Enoch 1: A Commentary on the Book of 1 Enoch Chapters 1-36; 81-108 (Minneapolis, 2001), p. xxiii.

${ }^{4}$ Ancient fudaism and Christian Origins: Diversity, Continuity, and Transformation (Minneapolis, 2003).

${ }^{5}$ Ancient Fudaism and Christian Origins, pp. 3 and 4.

${ }_{6}$ This impression is reinforced by a comment made in a different context about the ripple effect the changes in the understanding of the Greco-Roman literature ought to have on the field. "Ripples, however, do not always follow their predetermined path, either because they meet with counterforces or because they run up against the inertia of stationary objects. For reasons too complex to analyze here, much New Testament scholarship has had a love-hate, attraction-avoidance relationship with the modern study of early Judaism - drawing deeply from it at times and blissfully ignoring or even actively resisting it at other times." In "Wisdom and Apocalypticism in Early Judaism: Some Points for Discussion," in J. Neusner and A.J. Avery-Peck, eds., George W.E. Nickelsburg in Perspective: An Ongoing Dialogue of Learning (Leiden, 2003), p. 267. 
Christian origins in light of the new understanding of second temple Judaism is "the raison d'être for this book."

The second major work to come out in 2003, George W.E. Nickelsburg in Perspective: An Ongoing Dialogue of Learning, is no less ambitious. Jacob Neusner and Alan J. Avery-Peck have put together two volumes that present a cross-section of Nickelsburg's work, spanning his entire career from his first article, published in 1971, to the papers given during the 2001 Annual Meeting of the Society of Biblical Literature in honor of the much awaited publication of Nickelsburg's Enoch commentary, and a number of invited responses to Nickelsburg's work. The articles are reprinted in their original form and are each followed by a critical response from an expert on the topic. Finally Nickelsburg replies briefly to each response. The idea of this anthology is to create, as the editors put it, "a model, an alternative to the conventional Festschrift," that places the honoree at the center of his field and enables him "to define the program of debate, not only episodically through scattered articles and books, but cogently and systematically through collected articles, reread as a group." 9

This unconventional form of paying tribute to a preeminent scholar can already be deemed a success. Even though every selection of articles from a pool as impressive as Nickelsburg's life-long work inevitably involves some choice that is open to debate, ${ }^{10}$ the two volumes provide a helpful synopsis of the honoree's work. The goal, to foster scholarship through the promotion of debate, not on the person of George Nickelsburg, to be sure, but on some key issues of second temple Judaism he raises in his work, has already been accomplished, and this on multiple levels. Revisiting his earlier work, Nickelsburg is able to reflect on, refine and, at times, clarify his thought. In two cases the editors have selected two articles which Nickelsburg wrote on closely related topics, yet years apart - on the

7 Ancient Fudaism and Christian Origins, p. 7.

George W.E. Nickelsburg in Perspective, p. xii.

9 Ibid., p. xi.

10 Other seminal studies that would have added even more dimensions to Nickelsburg's work include "Scripture in 1 Enoch and 1 Enoch as Scripture," in T. Fornberg and D. Hellholm, eds., Texts and Contexts: Biblical Texts in their Textual and Situational Contexts, Essays in Honor of Lars Hartman (Oslo, 1995), pp. 333-54; and "The Nature and Function of Revelation in 1 Enoch, Jubilees, and Some Qumranic Documents," in E.G. Chazon and M.E. Stone, eds., Pseudepigraphic Perspectives: The Apocrypha and Pseudepigrapha in Light of the Dead Sea Scrolls (Leiden, 1999), pp. 91-119. 
book of Tobit (with articles from 1988 and 1996), ${ }^{11}$ and on the rich and the poor in Luke and the Epistle of Enoch (published in 1979 and 1998, respectively) - and here the second article functions as a commentary on the first. Most important, however, are the invited and helpful responses, not least because they assess Nickelsburg's arguments and also the progress made in the field since the articles were first published, as amply documented in the footnotes.

In light of the task brought before me, to evaluate the two volumes as a whole, not in bits and pieces, the aim of my brief reflection is to identify what I perceive to be the main objectives in Nickelsburg's work here collected. What are the major recurrent themes put forth in these articles, how are they related, and what are the implications they carry for our understanding of early Judaism and Christianity? The remarkable diversity of texts, themes, and methods notwithstanding, I propose that there are four principal concerns around which Nickelsburg's work revolves.

First and foremost, Nickelsburg's work is descriptive in nature. Nickelsburg provides his readers with detailed descriptions of a literature, which, when he began his publishing career, was largely inaccessible, its details unknown, and which even now remains on the fringes of the field. Nickelsburg is a master in the art of reading. Whatever his argument, it will be grounded in the most careful and detailed exposition of the text. One of Nickelsburg's preferred techniques of reading is the comparison of documents generally kept in segregation. In his own words, "over the years I have understood the literary and historical interpretation of Jewish literature to be an exercise in comparison and contrast." 12 The goal of this comparative approach is to bring to the fore the variegated relationships and correspondences between the texts that otherwise remain hidden. The results are often eye-opening and surprising. His articles on Tobit, for example, are based on the premise that the books of Tobit and 1 Enoch, even though they are traditionally grouped in different categories, both draw on "an older common stock of ideas, traditions, and terminology, not simply to be found in the Hebrew Scriptures, ${ }^{\prime 13}$ which each text then interprets in its own creative way.

${ }^{11}$ In a third article, "Tobit, Genesis, and the Odyssey: A Complicated Web of Intertextuality," in D.R. MacDonald, ed., Mimesis and Intertextuality in Antiquity and Christianity (Harrisburg, 2001), pp. 41-55, Nickelsburg takes his intertextual argument even further to include Jubilees and the "Reworked Pentateuch" from Qumran.

${ }_{12}$ George W.E. Nickelsburg in Perspective, p. 263.

13 Ibid., p. 219. 
In his reply, Robert Doran praises Nickelsburg for "his more daring suggestions ... to link Tobit and 1 Enoch" (p. 254), even though in the end he remains unconvinced by the relationships Nickelsburg's suggests.

In another article titled "Salvation Without and With a Messiah: Developing Beliefs in Writings Ascribed to Enoch" (chap. 3), Nickelsburg compares the different sections of 1 Enoch. Throughout his work, 1 Enoch, "arguably the most important text in the corpus of Jewish literature from the Hellenistic and Roman periods," 14 serves as the lens through which Nickelsburg views second temple literature in general. The point of the article is to argue that varietyin this case the variety of messianic beliefs within the corpus of Enochic writings - was a salient feature of early Jewish eschatology. The main implication of Nickelsburg's first, descriptive concern, then, is to make accessible a corpus of literature that has been relegated to the study of a few specialists, who are fluent in Ethiopic, Syriac, and Old Church Slavonic, and to point to the numerous connections that exist both between the texts and within larger compositions such as the Enochic writings.

This "comparative instinct," 15 as Nickelsburg calls it, inevitably leads to the second, frequently recurring theme in his work, his persistent concern with methodological issues. Here Nickelsburg's work is just as innovative, yet his ideas are more controversial. In order for Nickelsburg to take a fresh look at the ancient texts, often through uncommon juxtapositions, he has to overcome certain boundaries between the documents that hide their original correspondences. Such boundaries come in different forms and guises. Some are the result of the biblical canons, which in effect create two classes of ancient writings, texts that were canonized and those that were not. Nickelsburg has been rather outspoken about the need for the extra-canonical Jewish literature to be assigned a fixed place in biblical studies. "I hope to demonstrate that Jewish and Christian biblical scholars need to study these texts even though the texts do not have canonical authority in their respective traditions." 16

141 Enoch 1, p. 1.

15 George W.E. Nickelsburg in Perspective, p. 263.

16 This is Nickelsburg's concluding remark in the introduction to his programmatic study, "Why Study the Extra-Canonical Literature? A Historical and Theological Essay," pp. 687-713 (the quote is on p. 688). See also George W.E. Nickelsburg in Perspective, pp. 362-63. 
The exclusive focus on the canonical texts to the exclusion of the non-canonical material skews the historical perspective, not least because the extra-canonical Jewish literature of the Greco-Roman period is an integral part of the ongoing history of Israelite religious tradition. Such exclusionary view ultimately will have grave theological implications for our understanding of Judaism, and subsequently for emerging Christianity. Nickelsburg provides several concrete examples in which commonly held theological positions turn out to be based on "Christian myth" 17 rather than on a careful reading of the documents. One of these examples is the prevailing "cliché"18 that prophecy ceased during the Persian period, when in fact the evidence from the Greco-Roman period attests a plethora of often competing claims to revelation or inspiration. Another example is the portrayal of the Jewish religion as a foil to Christianity. This caricature of Judaism can quickly be identified for what it is as soon as the continuous, multivalent developments of Judaism from the late biblical into the early rabbinic period are recognized. Nickelsburg is right to raise this issue. It uncovers how seemingly historical descriptions are theologically motivated. It also stresses the importance for a reevaluation of second temple literature. Some of this has begun to happen lately, but much remains to be done. ${ }^{19}$

Yet there are boundaries of a different sort as well, imposed not by canons but by scholarly rubrics and terminology. Over and over Nickelsburg warns that modern critical categories, helpful as they are, should not be employed in too rigid a fashion. Once labels become hermetically sealed and impermeable, they compartmentalize texts and obscure, rather than explain, intrinsic connections among the texts. Nickelsburg explicitly comments on this danger in one of the more programmatic articles of the collection, his 1994 essay "Wisdom and Apocalypticism in Early Judaism: Some Points for Discussion," an article intended to set the agenda for the Society of Biblical Literature Group on Wisdom and Apocalypticism in Early Judaism and Early Christianity. He writes, "[t]he history of scholarship indicates that we have sometimes confused our scholarly abstractions and heuristic categories with flesh and blood realities in

17 George W.E. Nickelsburg in Perspective, p. 705.

18 Ancient Judaism and Christian Origins, p. 96.

19 See, for example, L.L. Grabbe, Judaic Religion in the Second Temple Period: Belief and Practice from the Exile to Yavne (London and New York, 2000). 
the ancient culture that we study. Terms like sapiential, apocalyptic, and eschatological are useful and, indeed, necessary, but they must be seen for what they are: windows into another world, means for trying to understand that to which we do not have first hand access. It is imperative that the means not be construed as the end, or the window, as the landscape. ${ }^{\prime 20}$

Two categories in particular, according to Nickelsburg, are much more compatible than is generally conceded, wisdom and apocalyptic. Nickelsburg explains, "the entities usually defined as sapiential and apocalyptic often cannot be cleanly separated from one another because both are the products of wisdom circles that are becoming increasingly diverse in the Greco-Roman period." ${ }^{21}$ As a result, scholars will label texts either as wisdom or as apocalyptic, even if they have elements of both. Nickelsburg makes this argument specifically with respect to Tobit and 1 Enoch, and the Wisdom of Solomon, a text that figures prominently in his articles, and which he lists under the intriguing rubric "texts that complicate the categories." 22 He also warns of a dichotomous juxtaposition of wisdom and apocalyptic in his reply to John Kloppenborg, arguing that whereas the New Testament book of James would be considered a sapiential book, its world view and message are generally associated with "apocalyptic" literature. ${ }^{23}$

While in principle it is difficult to see how anyone could take issue with Nickelsburg's persistent warning not to confuse scholarly abstractions with the textual realities of the Greco-Roman period, reactions to Nickelsburg's work suggest that the issue is not uncontested. In her insightful response to Nickelsburg's article, Sarah Tanzer, Nickelsburg's long-time colleague in the SBL Group, points out that while considerable debate has been devoted to agreeing on a definition of terms such as apocalypse and apocalypticism, the same does not hold true for definitions of wisdom. Indeed, trying to find a definition of Wisdom literature that determines which works belong and which do not scholars have proposed a set of "types of wisdom." 24 Such

${ }^{20}$ George W.E. Nickelsburg in Perspective, pp. 267-87 (the quote is on p. 285).

${ }^{21}$ Ibid., pp. 269-70.

22 Ibid., p. 277

${ }^{23}$ Ibid., p. 588.

24 Tanzer, pp. 290-291, mentions explicitly J.L. Crenshaw, Old Testament Wisdom: An Introduction (Atlanta, 1981), p. 17, and J.J. Collins, "Wisdom, Apocalyptic and Generic Compatibility," in L.G. Perdue, et al., eds., In Search of Wisdom: Essays in Memory of John G. Gammie (Louisville, 1993), p. 168. 
attempts to create even more sub-definitions might, from Nickelsburg's point of view, easily seem more restrictive than helpful.

The issue of genre recognition also played a significant role in the responses to Nickelsburg's commentary on 1 Enoch. John Collins in particular takes issue with Nickelsburg's discussion of literary forms. Collins strongly rejects Nickelsburg's attempt to reconstruct a testament as an early form of 1 Enoch as "unduly speculative," noting that Nickelsburg never provides a discussion of the genre testament. ${ }^{25}$ Also, Collins explicitly points out that Nickelsburg, while speaking favorably of the analysis of the genre 'apocalypse' in Semeia 14, omitted the term in his discussion of literary forms in 1 Enoch. In a somewhat startling comment, Collins suggests that this "may be no more than an oversight." ${ }^{26}$ Nickelsburg's reply makes clear, however, that the omission is hardly the result of an oversight. While Collins calls for clearly demarcated literary forms under which the texts can be subsumed, Nickelsburg wants to move away from the general umbrella genres like "apocalypse." He prefers revealed wisdom as a central category, thus moving away from the more conventional genres. "Perhaps the precipitate of this exchange is that we need to review our understanding of genre, with an eye toward form and content, a recognition that genres are often mixed, and some consideration of the fact that our terminology (in this case 'apocalypse') is our own." ${ }^{27}$ In concrete terms, Nickelsburg speaks of the "Animal Vision" rather than "Animal Apocalypse," because the author employs the term "Vision" and not "Apocalypse." And he labels 1 Enoch 85-90 "Historical Reviews," because this seems to him the most accurate description of the text. Rather than bringing the genre to the text, he derives his terminology directly from the text, always being mindful of significant overlap in form and language between distinct genres.

A third, frequently recurring concern in Nickelsburg's work is his attempt to reach behind the text, as it were, to detect the institutions and social settings from which these texts emerged. ${ }^{28}$ Nickelsburg's

25 George W.E. Nickelsburg in Perspective, p. 376.

26 Ibid., p. 377.

7 Ibid., p. 411.

28 This is one of Nickelsburg's long-standing interests. As early as in a 1979 paper, "Social Aspects of Palestinian Jewish Apocalypticism," in D. Hellholm, ed., Apocalypticism in the Mediterranean World and the Near East (Tübingen, 1989, second ed.), he uses the Epistle of Enoch (1 Enoch 92-105) as a test case to demonstrate the 
discussion is inextricably linked with, and, in fact, the direct result of, his methodological plea to view categories such as "wisdom" and "apocalyptic" for what they are, scholarly constructs. He concludes his article "Wisdom and Apocalypticism in Early Judaism" urging his readers to "think holistically" about the past and "to study texts in context." Thus he writes, "texts are historical artifacts. As we try to understand the functions they fulfilled and the settings in which they were employed, we may discover that the similarities in texts that we have decided belong to different categories are not really all that strange after all, because in the wholeness of life in antiquity they were tied together in ways we have yet to understand." ${ }^{29}$ In other words, while texts are categorized under distinct literary genres, they may nonetheless stem from community settings that show significant breadth: schools, synagogues, the Temple court, closed conventicles or open market places. Specifically, it was the function of the scribes and the wise in the Greco-Roman period to interpret Torah and to study the Prophets. Thus emerged circles of learned interpreters mentioned in Ben Sira, 1 Enoch, Daniel, the Wisdom of Solomon, and the Qumran texts, community leaders and sages who derived their ethical instruction from the Torah, cast their message in the genres used by the prophets, and spoke in the idiom of the ancient wisdom tradition. ${ }^{30}$

The effort to reconstruct the institutions that gave rise to these texts is not a mere afterthought in Nickelsburg's work but serves a larger purpose. The real argument here, which Nickelsburg makes passionately throughout his writings, though with increasing vigor in his more recent work, is an argument for diversity of early Judaism. ${ }^{31}$

methodological difficulties. On the Epistle and how it relates to the fragments from Qumran, see also his article "The Epistle of Enoch and the Qumran Literature," as well as the response by G. Boccaccini, George W.E. Nickelsburg in Perspective, pp. 105-37.

${ }_{29}$ George W.E. Nickelsburg in Perspective, p. 286 (italics in the original).

${ }^{30}$ Ibid., p. 283

31 Nickelsburg is hardly alone in calling for a differentiated view of Second Temple Judaism. Numerous publications have addressed the problem and proposed different models regarding the essence and variegated nature of Judaism. Among the most recent studies are M.S. Jaffee, Early Judaism (Upper Saddle River, 1997); S.J.D. Cohen, The Beginnings of Jewishness: Boundaries, Varieties, Uncertainties (Berkeley, 1999); J. Neusner, The Four Stages of Rabbinic Fudaism (London, 1999); J. Neusner, Fudaism When Christianity Began: A Survey of Belief and Practice (Louisville, 2002); G. Boccaccini, Roots of Rabbinic Fudaism: An Intellectual History From Ezekiel to Daniel (Grand Rapids, 2002); and L.H. Schiffman, Texts and Traditions: A Source Reader for the Study of Second Temple and Rabbinic Fudaism (Hoboken, 1998). 
Josephus's description of a handful of Jewish groups is misleadingly simplistic. "As I have emphasized in other responses in this volume, we need to recognize and try to give shape to the religious and social variety of early Judaism. Hasidim, Pharisees, Sadducees, Essenes, and Zealots are no longer tenable as an exhaustive descriptive scheme." ${ }_{32}$ Here Nickelsburg is taking on what he rightfully perceives to be a fundamental flaw in the portrayal of first century Judaism in biblical scholarship. The erroneous, yet persistent, notion of a "normative Judaism" has its origin in theological judgments that are based on defective historiography, when in fact the texts attest to a dynamic and variegated set of ancient Jewish groups and institutions. Old stereotypes are beginning to collapse as traditional descriptions of early Judaism are being revised.

Such descriptions of first century normative Judaism as an aberration of the true prophetic religion are theologically motivated: they seek to view Judaism as the dark foil against which Christianity shines bright. The fourth principal concern in Nickelsburg's work, then, is to uncover the developments that led to the emergence of Christianity, in an effort finally to dispel such misconstrued notions of first century Judaism and Christianity. Nickelsburg's work on early Christianity, seen as a whole, is marked by the confluence of several of his longstanding interests. For one, he argues compellingly that Christianity shares several of its religious viewpoints with the apocalyptic strands of Judaism, particularly with the Qumran community and Enochic sectarianism..$^{33}$ Not least among these is the idea that salvation belongs exclusively to a community constituted by an eschatological revelation. ${ }^{34}$ Also, Nickelsburg makes much of the sacred geography of

32 George W.E. Nickelsburg in Perspective, p. 361.

33 Nickelsburg makes this point repeatedly, though particularly important are two of his essays, "Jews and Christians in the First Century: The Struggle over Identity," and "Why Study the Extra-Canonical Literature? A Historical and Theological Essay" (George W.E. Nickelsburg in Perspective, pp. 613-41, and 687-713); also see his discussion in 1 Enoch 1, pp. 82-95. Patrick Tiller concurs, "1 Enoch attests to a form of pre-Christian Judaism that looks in some (limited) ways more at home in Christianity than in Judaism as it has been traditionally understood" (George W.E. Nickelsburg in Perspective, p. 370). Also Ancient Judaism and Christian Origins, pp. 185-200. G. Boccaccini, Beyond the Essene Hypothesis: The Parting of the Ways between Qumran and Enochic Fudaism (Grand Rapids, 1998), argues that the earliest roots of Christianity are found in Enochic Judaism.

34 The issue of what constitutes a sect, at Qumran and elsewhere, is taken up by Carol Newsom in her instructive response to Nickelsburg's article "Religious Exclusivism: A World View Governing Some Texts Found at Qumran." Referring 
1 Enoch and some early Christian texts. Both attribute special significance to the region of the upper Galilee and may well derive from there. ${ }^{35}$ Yet of ultimate importance for Nickelsburg is, once again, the notion of diversity and continuity, diversity in the religious expression of both second temple Judaism and early Christianity, and continuity between these variegated forms of Judaism and Christian traditions about Jesus of Nazareth.

The point cannot be made emphatically enough. The damage done by simplified misconceptions of ancient Judaism is considerable, and Nickelsburg is right to call for a major clean-up operation. There is a telling difference in the way Nickelsburg makes his point in Ancient Judaism and Christian Origins and George W.E. Nickelsburg in Perspective, however. In the former, as note above, the examples he chooses to compare Judaism and Christianity are deliberately traditional, whereas in the articles Nickelsburg is concerned with relatively unconventional aspects (e.g., sacred geography, issues of wealth and poverty in Luke and in the Epistle of Enoch, or the constitutive elements of the Markan passion narrative) ${ }^{36}$ The former approach seems more promising than the latter. The task of reevaluating our hypotheses about the beginnings of Christianity in light of the recent changes in the field of Second Temple Judaism is monumental and its implications far reaching. It can only be accomplished when traditional New Testament scholarship is engaged to a significant degree, more so than Nickelsburg has done in his articles, and when the core issues of New Testament studies are brought to the table.

to a recent article by Jutta Jokiranta, Newsom writes, "The two variables that form the parameters for sectarianism are the degree of tension with the socio-cultural environment and 'the extent to which a religious group considers itself to be uniquely legitimate"" (George W.E. Nickelsburg in Perspective, p. 163).

35 The argument here is that the region around Mt. Hermon was considered sacred territory by Canaanites, Israelites, Greeks, Romans, and Christians from the third millennium B.C.E. to the middle of the first millennium C.E.; see "Enoch, Levi, and Peter: Recipients of Revelation in Upper Galilee," George W.E. Nickelsburg in Perspective, pp. 427-68; and his excursus "Sacred Geography in 1 Enoch 6-16," in 1 Enoch 1, pp. 238-47. In response, J.C. VanderKam remains skeptical about how much can be inferred from the brief geographical reference in the Book of the Watchers, but Nickelsburg makes his case again and anchors it in the significance Dan and Hermon have had as sacred territory over a long period of time (George W.E. Nickelsburg in Perspective, pp. 412-13).

${ }^{36}$ On the latter, see the exceptionally lucid and clarifying response by L.M. Wills, George W.E. Nickelsburg in Perspective, pp. 504-12. 
Not many scholars can claim that their scholarship is instrumental in bringing about some substantial changes in their academic disciplines. Nickelsburg's work is doing just that, and a whole new picture of Second Temple Judaism is beginning to arise. His success derives to no small degree from the persistency with which he probes ancient Jewish literature, describing it, overcoming methodological difficulties, detecting its variegated social settings, and spelling out the implications all of this has for our understanding of early Christianity. 